\title{
Industrial Tourism Attractions. The Case of Salt Mines in Romania
}

\author{
Iulian Adrian SORCARU ${ }^{\star}$
}

\begin{tabular}{l} 
A R T I C L E I N F O \\
\hline Article history: \\
Accepted March 2021 \\
Available online April 2021 \\
\hline JEL Classification \\
Z3, Z32 \\
Keywords: \\
Industrial heritage, Salt mines, \\
Speleotherapy, Pure consumer \\
Tourism, Medical tourism
\end{tabular}

\section{Introduction}

Industrial tourism is the form of tourism that involves visiting operational industrial companies and capitalizing on industrial heritage, while offering unique experiences, understanding the finished products, the technological flow, the history of certain economic activities, etc.

One of the theoretical approaches in the published studies on industrial tourism considers its contribution to the development of companies in which visit tours are organized, as well as to the economic development of the neighboring regions. Thus, it can generate an increase in the number of jobs and a reduction in the unemployment rate for the resident population, by diversifying the tourist products. For the neighboring regions, the industrial tourism represents a potential sector of economic growth, being associated with their identity. At the same time, many regions, urban or rural, although they have the opportunity to develop their industrial heritage, fail to capitalize on its true value (Otgaar et all, 2016). In most cases, industrial tourism is limited to organized tours of some companies, without a clear vision of their management on medium and long term strategic development. The reasons are related to the fear of some companies of possible leaks of confidential information about the business or the lack of security. At the same time, there are companies that appreciate the opportunities for the development of industrial tourism that can help them to promote and sell their products and increase the visibility.

The first tourist trips to visit some industrial companies were organized over a century ago at certain wineries and chocolate factories in France, lace factories in Greece and Malta and cheese producers in the Netherlands (Otgaar et all, 2016). In Paris, starting with 1900, tourist tours of textile factories or slaughterhouses were organized for tourism purposes. People could also visit the tobacco factory, the headquarters of the stock exchange, the parliament building and the court of justice.

At the same time, in the USA, industrial tourism has a much longer history, starting from Jack Daniel's distilleries in Tennessee that could be visited by tourists/residents since 1866, the year the company was founded (Frew, 2000).

In Romania, although industrial tourism is practiced on a much smaller scale compared to other European regions, the industrial heritage is capitalized by including in the tourist circuit the following categories of tourist attractions: the salt mines of Turda, Slanic Prahova and Targu Ocna; winemaking process and visiting the wineries from Recaș and Rhein Azuga; the Roșia Montana mines (Iancu Merciu, C., Stoica, I., 2010). 
Some authors consider that industrial tourism is a subcategory of archaeological tourism, an idea argued by the fact that certain closed industrial units can be capitalized in tourism activities, serving to reconstruct and learn the history and culture of some regions (Innocenti, 2007).

In this context, the concept of "industrial archeology" appeared, preceding "industrial tourism" which studied the industrial equipment used over time, as well as the means of transport, production, traditional products, etc. At the same time, the doctrine of industrial archeology also covers the economic and social consequences of the industrial revolution.

Thus, some economic units can be capitalized by practicing industrial tourism or even saved from closure (Corti, 1991). In some regions, the main reason for tourists to travel is precisely the industrial heritage that gives tourists the opportunity to know the local history (Preite, Maciocco, 2000).

Although, the international literature addressing industrial tourism was consistent in the last decade, addressing both theoretically/empirically its characteristics or customizing for a number of regions worldwide, in Romania studies dedicated exclusively to this form of tourism are few, most of them limited to specific reviews of tourist attractions. Therefore, the study aims to analyze the tourism phenomenon specific to salt mines in Romania, the major objectives being: analyzing of the dynamics of inbound tourist flows; analyzing of the dynamics of the existing accommodation units in their surroundings; analyzing the economic impact on the resident population from the neighboring regions.

\section{Literature review}

Industrial tourism, although not a new form of tourism, is a concept that is little explored in the literature, with different meanings. In 1974 Simonson defined industrial tourism as "visits to the site of a production facility which can include educational tours of the facility, sampling of the product and the possible purchase of the product and/or souvenirs" (Simonson, 1974). A similar definition was mentioned by other researchers two decades later (Dodd, 1998).

Soyez (1986) defined industrial tourism (industrietourismus) as a group name for visits to operational and non-operational firms: "every kind of movement that can be deduced to the appeal of either operational or former industrial systems". So, according to Soyez definition, industrial tourism is defined by the visitor's reason to visit. For example, when someone visits a zoo to see certain animals, is considered a regular tourist, but when the visit is made to learn more about how a zoo functions, the visitor is considered an industrial tourist. Also, Soyez mentioned three types of visitors, as follows: business visitors (engineers visiting other companies); educational visitors (teachers, students, scholars); other visitors (leisure tourists, participants of company outings, civil servants).

Frew (2000) defines industrial tourism as "visits by tourists to operational sites where the core activity of the site is non-tourism oriented." Industrial tourism is in her view more than factory tourism: all sectors of the economy can open their doors for industrial tourists. In her opinion industrial tourism is somewhere in between "pure industry" and "pure consumer tourism", producing goods and services for both the general public and tourists. She also provides a comprehensive overview of other concepts related to industrial tourism. These concepts are presented along two axes: from consumer tourism to industrial tourism along one axis and from specific named tourism attractions to more general concepts along the other.

Since 2000, many authors in Europe use terms for phenomena, more or less equal for industrial tourism: technical visits, company tours, factory tours, industrial attractions, industrial sightseeing. Also, many papers on industrial tourism actually focus on food and beverage tourism which can be seen as a specific type of industrial tourism (Plummera et al., 2003; Hall \& Sharples, 2003; Telfer \&Hashimoto, 2002).

\begin{tabular}{|c|}
\hline Pure Industry \\
Production of goods \\
and/or services for the \\
general public only. \\
Tourists are not admitted \\
(e.g. a site which is unsafe \\
or unsuitable for tourists)
\end{tabular}

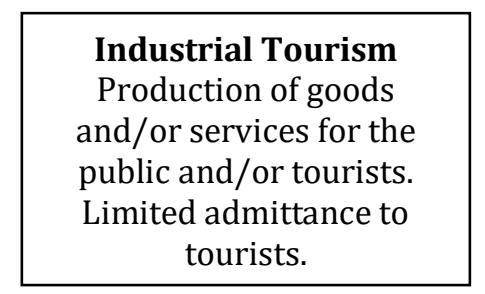

Industrial Tourism

Production of goods and/or services for the public and/or tourists tourists.
Pure Consumer Tourism
Production of goods and/or services for tourists only.
Tourists are admitted, but they do not experience the "behind the scenes" aspects of operating an attraction

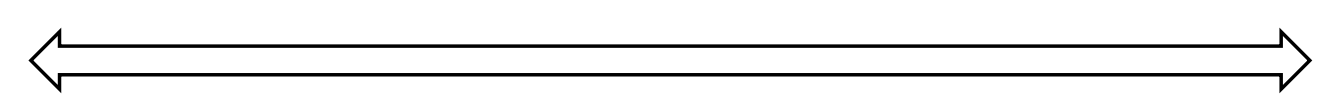

Figure 1. Tourism Characterized by the Market for the Goods and the Services (source: Frew, 2000; adapted by Otgaar, 2010) 
Another view on industrial tourism defines company visits as a subgroup of economic discoveries. Thus, economic discoveries include the following categories (Marcon, Preiulh\&Ksouri, 2000):

- company visit tourism which involves visits to operational sites of firms in all sectors of the economy;

- industrial heritage tourism which includes heritage sites and museums where visitors can learn about former economic activities;

- science tourism which comprehends museums, cultural and science centres, etc.

The same authors subdivided the first category (company visit tourism) into three sub-categories: open doors-companies that open their site without modifying their production units. These firms just show how they operate; communication centres-companies that have duplicated their production units in visitor centres. Visitors are often accompanied by professional guides; commercial units- companies that treat visits as a commercial activity. They open a shop and/or other commercial units near the production site.

In Romania, Law no. 6/2008 on the legal status of technical and industrial heritage, includes the elements of industrial archeology in the cultural heritage. Defining the technical and industrial heritage and considering it as important as other traditional cultural assets was the main purpose of the law.

Also in 2008, the Ministry of Culture and National Heritage included in the classification of tourist resources, technical and industrial heritage goods, along with other types of tourist resources that form the cultural heritage of Romania (museums and collections, monuments and archaeological sites, etc.) (The Ministry of Culture and Religious Affairs' strategy concerning the national cultural heritage, 2008, p. 16).

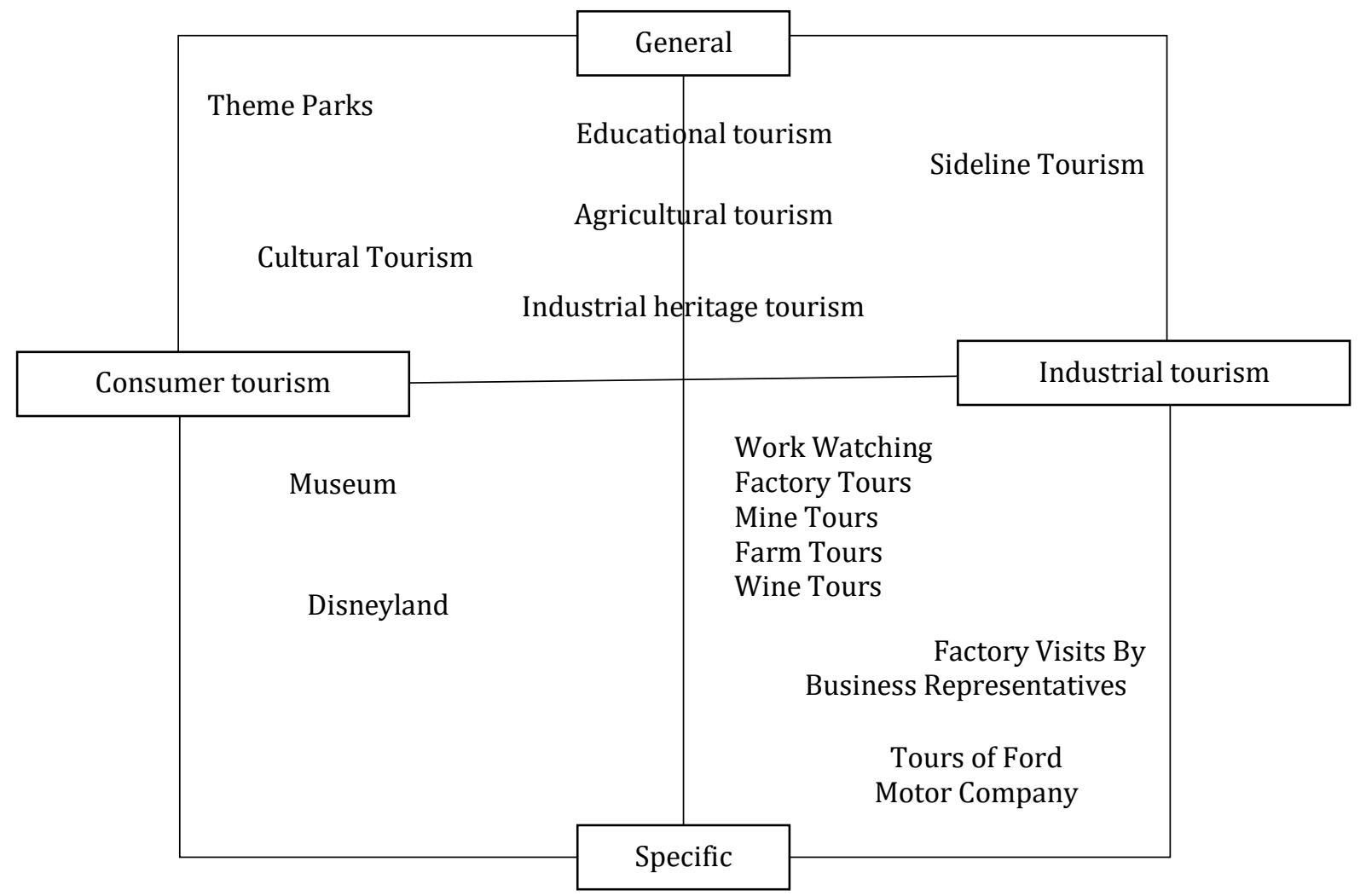

Figure 2. General and Specific Types of Consumer and Industrial Tourism (source: Frew, 2000; adapted by Otgaar, 2010)

\section{Methodology and Results}

The research is based on data provided by the National Institute of Statistics, Bucharest on the dynamics of tourist circulation, the number of accommodation units and accommodation capacity in the last three decades in the proximity of the salt mines in Romania opened to visitors (Turda municipality, Târgu Ocna town, Slănic town, Ocnele Mari town, Praid commune, Cacica commune). Their correlation with the investments made and the forms of tourism practiced, as well as the comparative analysis of the salt mines opened to tourists and highlighting of the gaps in capitalizing the tourist potential, were made based on data provided online by companies managing the salt mines and on international literature.

The methods used to achieve this study were the method of analysis, graphic and comparative. The graphic materials, indispensable to all researches, were made using available softwares in order to illustrate and compare the information suggestively. 
Since the last centuries, salt mines have been known for their therapeutic properties. The saline air environment, with constant temperatures of about 11-16 degrees Celsius and a high humidity of over 70\%, is recommended for most respiratory diseases (asthma, bronchitis, etc.). The salt mines in Romania, both closed and opened to visitors, have arranged special areas for people suffering from various respiratory diseases, being equipped with a varied leisure infrastructure. Thus, the salt mines in Romania are known and visited, both by Romanian and foreign tourists, for medical tourism. At the same time, leisure activities have been encouraged over time, through the facilities in most mines that are distributed evenly inside Romanian borders. Next, we will briefly present the most important landmarks regarding the history, location and tourist facilities of the most famous salt mines in Romania: Turda, Praid, Slănic-Prahova, Tg. Ocna, Ocnele Mari and Cacica.

Turda salt mine opened in the 17 th century, was being competed after 1840 by Ocna Mureș mine. Its geographical position is favorable, being located about 36 kilometers from Cluj-Napoca and 6 kilometers from Turda. During World War II it was used as a shelter for bombs, continuing to be a storage space until 1992, when it was transformed into a theme park. Currently, tourist facilities focus on leisure and include a mini golf course, an amphitheater, a bowling alley, sports fields, an anthropic lake.

Slanic Prahova salt mine is located in Slănic town administrative unit in Prahova County, being opened in 1943 and having 15 rooms with trapezoidal profiles. The salt was mined until 1972, after which the mine became a tourist attraction. The accessibility of the mine is ensured by minibuses that transport tourists to a depth of 208 meters. This tourist attraction of industrial origin also focuses on medical and leisure tourism, the factors that determine the practice of these forms of tourism being the constant temperature of 12 degrees Celsius throughout the year, humidity of $50 \%$, air composition rich in sodium ions and the absence allergens. They create a particularly effective microclimate in the treatment of respiratory diseases, and this makes the mine quite popular among tourists. At the same time, the salt mine has many leisure attractions (sports fields), with numerous busts and salt sculptures of some outstanding personalities of Romania. Thus, in the Genesis Hall room there are the salt busts of the king of Dacia, Decebalus and of the Roman emperor Trajan, the bust of the well-known Romanian poet Mihai Eminescu and a bas-relief of the great ruler Mihai Viteazul. In addition, the mine also has the Supernova Planetarium, being considered the largest planetarium in the country.

Praid salt mine is located in Harghita County, in eastern Transylvania and managed to attract over 640000 visitors in 2017, with an average annual underground temperature of about 16 degrees Celsius. The mine features a variety of leisure facilities, including Wi-Fi, children's playgrounds, a 3D cinema, a café and a restaurant.

Cacica salt mine is located in Suceava County, 40 kilometers from the city of Suceava and 450 kilometers from Bucharest, being accessible by wooden steps covered with a mineralized layer of salt of over two centuries old. Tourists can visit the underground church of St. Varvara, the small Orthodox chapel, some being attracted by the underground salt lake. A small museum has also been set up showing the history of the mine and the work of the miners. Leisure tourism is also practiced in Cacica, saline aerosols with therapeutic effects and a constant temperature of about 14 degrees Celsius being the reasons why most tourists visit the salt mine.

Ocnele Mari salt mine is located in Ocnele Mari town, 8 kilometers from Ramnicu Vâlcea, near Olt Valley, being one of the oldest in the country. The mine is situated at 225 meters above sea level and has an area of 10000 square meters. As in the case of the other salt mines, tourist facilities were designed for leisure and relaxation of the tourists. Thus, Ocnele Mari salt mine has a museum, a restaurant, souvenir shops, sports fields, playgrounds for children. The temperature in the underground is about 13-15 degrees Celsius, and the humidity is about $50 \%$, the mine being accessible by minibus.

Târgu Ocna salt mine is located in Bacău County, being the third largest salt mine in Romania. It has the largest treatment base in the country, at a depth of 240 meters and offers conditions for relaxation, leisure and treatment of respiratory diseases for visitors. Inside there are cultural tourist attractions: a museum of salt formation and exploitation and a church dedicated to Saint Varvara.

The existing tourist facilities inside the salt mines that can be visited in Romania, show that this industrial heritage is mainly used for health tourism. Because it is widely known and recognized the efficiency of treatment in salt mines, especially in pulmonary diseases, the development of speleo - therapy is extremely actual nowadays in Romania. The medical Romanian research carried out in the last few decades of the 21st century are allowing the more and more efficient use of the natural therapeutic factor - saline micro - climate - for the prophylaxis, treatment and recovery in respiratory, dermathological, imunological and other diseases. At the same time, thematic museums were created (Salt Museum in Slănic Prahova; Turda History Museum in the former Salt Chamber House) which presents exhibits used in the past in the economic activity of salt exploitation, as well as information about the technological process for salt extraction.

The possibility to visit the companies that currently exploit the salt from the Romanian mines, is limited, being accessible, with the permission of the companies' management, only to small groups of visitors, specialists from various fields, who practice rather scientific tourism, reflecting the latent state of the industrial tourism potential specific to these tourist resources. 
Analyzing the latest data available for the number of visitors of the most important salt mines in Romania, we can see that in 2018, the first two places are occupied by Turda and Praid, with approximately 690000 and 656697 visitors, being followed by Târgu Ocna and Slănic Prahova salt mines with about 230000 and 225000 visitors.

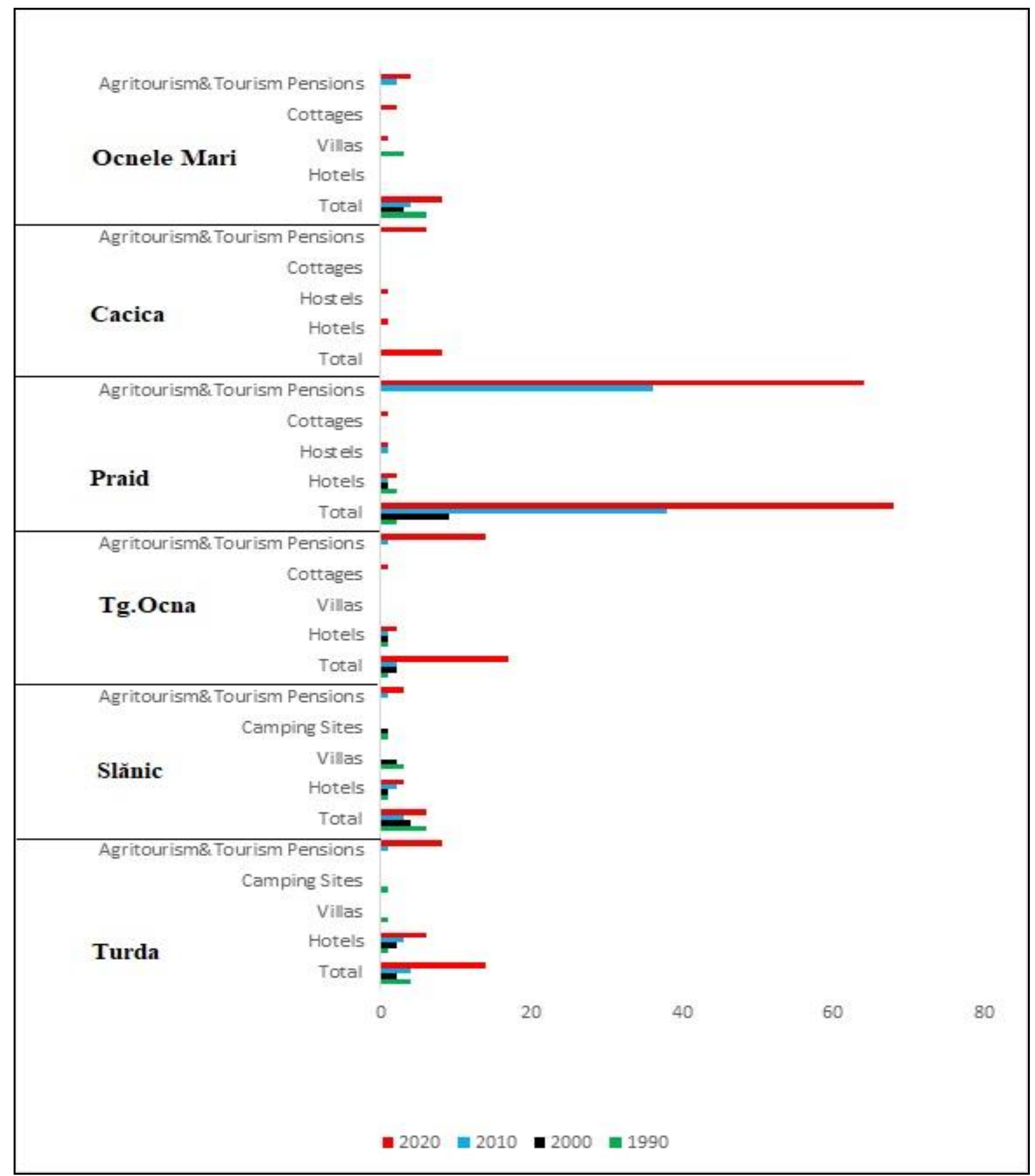

Figure 3. The Number of Accommodation Establishments by Type in the Administrative-Units Near the Salt Mines in Romania during 1990-2020

(source: INS, Bucharest, Tempo-Online Database)

This hierarchy is closely related to the level of investments made by local authorities, especially in the case of Turda mine, investments that generated the emergence of new tourist facilities and/or modernization of those existing before 2010. Thus, for Turda salt mine, 2008 is an important moment, since, within the PHARE 2005 CES program, large regional/local infrastructure, the mine is subject to an extensive process of arrangement and modernization, and since January 2010 it becomes an integral part of the Romanian tourist circuit. Also, the project "Increasing the tourist attractiveness of the area with spa potential - Durgău area, Valea Sărată and Salina Turda" was achieved by Turda Local Council in partnership with Cluj County Council and obtained funding under the Financing Scheme for Large Infrastructure Projects, Phare 
Program 2005. With this financial support from the European Union, in 2009 the development of Turda Salt Mine for tourist and curative purposes were carried out. At the same time, the economic impact on the company that manages the mine, as well as on the population of Turda municipality was a favorable one. Compared to 2017, when the company had a net turnover of 19 million lei and a net profit of 5.2 million lei, in 2018 the turnover of the salt mine increased by approximately 14\%, and the profit recorded an increase of 18\%. If in 2017, 134 employees worked in the Turda salt mine, in 2018 their number increased to 139, according to data provided by the Ministry of Finance.

Praid salt mine was also developed with the investments made by the National Salt Society, taking advantage by its position, near Sovata resort, extremely popular in Romania. Thus, most tourists who arrive in Sovata resort for relaxation or treatment, also visit the Praid salt mine.

In the same time, the dynamics of the number and accommodation capacity located in the vicinity of the salt mines during 2010-2020, as well as the inbound tourist flows of the last two decades, reflect, on the one hand, favorable developments and, on the other hand, considerable gaps. Thus, the total number of accommodation units has registered in the last decade an increase between $+78.9 \%$ (Praid commune) and + $750 \%$ (Tg. Ocna town), the most important increases being registered by the tourist and agrotourism pensions (+ 1300\% -the city of Tg.Ocna; $+700 \%$ - the municipality of Turda) (Figure 3).

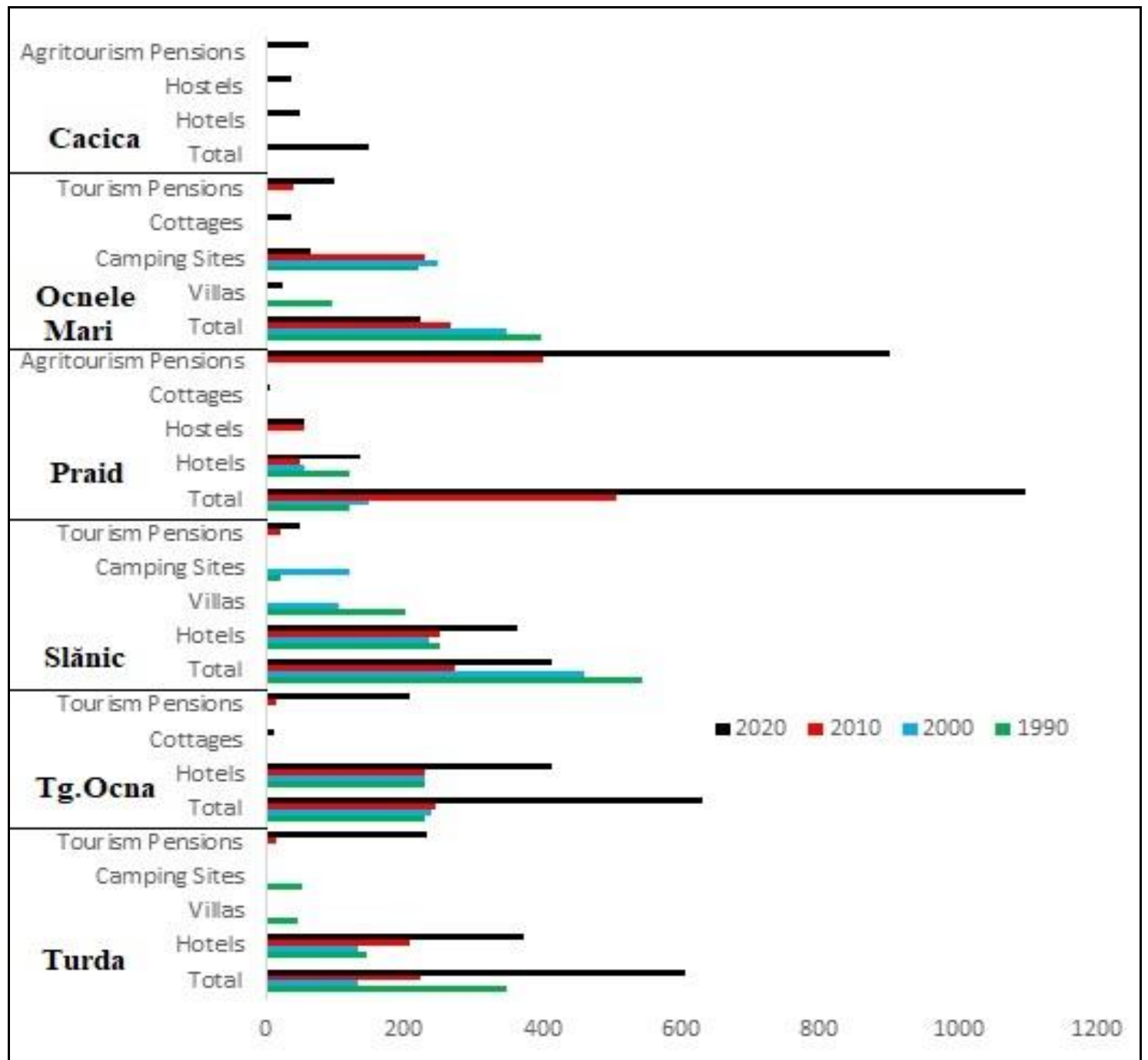

Figure 4. The Accommodation Capacity (Number of Bed-Places) by Type in the Administrative-Units Near the Salt Mines in Romania During 1990-2020 (source: INS, Bucharest, Tempo-Online Database)

Related to this evolution of the number of accommodation units, was also the dynamics of the accommodation capacity, Turda $(+171.3 \%)$ and Tg.Ocna $(+156.9 \%)$ being the administrative-territorial units with the larger increases in the total number of accommodation bed-places in the last decade (Figure 4).

In the figure presented above, Cacica commune, the administrative-territorial unit to which the Cacica salt mine belongs, the first classified accommodation units appear after 2010, which, even if it does not allow us an analysis of their dynamics, shows an upward tourist demand for nearby tourist attractions. This upward trend in tourist demand, connected with the "explosion" of the number of accommodation units, is 
argued both by the dynamics of salt mine visitors and by the number of tourist arrivals registered by classified accommodation units existing in their vicinity (Table 1).

Table 1. Tourist Arrivals in the Administrative Units Near the Salt Mines in Romania during 2001-2019

\begin{tabular}{|c|c|c|c|c|c|}
\hline \multirow{2}{*}{$\begin{array}{c}\text { Administrative } \\
\text { Unit }\end{array}$} & \multicolumn{5}{|c|}{ Number of Tourist Arrivals } \\
\cline { 2 - 6 } & $\mathbf{2 0 0 1}$ & $\mathbf{2 0 1 0}$ & $\mathbf{2 0 1 9}$ & $\mathbf{2 0 0 1 - 2 0 1 9}(\%)$ & $\mathbf{2 0 1 0 - 2 0 1 9}(\%)$ \\
\hline Turda & 8510 & 9384 & 35562 & $\mathbf{+ 3 1 7 . 9}$ & $\mathbf{+ 2 7 9 . 0}$ \\
\hline Tg. Ocna & 7210 & 5381 & 12635 & $\mathbf{+ 7 5 . 2}$ & $\mathbf{+ 1 3 4 . 8}$ \\
\hline Slănic & 6828 & 7422 & 9460 & $\mathbf{+ 3 8 . 5}$ & $\mathbf{+ 2 7 . 5}$ \\
\hline Praid & 1334 & 2568 & 31544 & $\mathbf{+ 2 2 6 4 . 6}$ & $\mathbf{+ 1 1 2 8 . 3}$ \\
\hline Ocnele Mari & 1322 & 507 & 2859 & $\mathbf{+ 1 1 6 . 3}$ & $\mathbf{+ 4 6 3 . 9}$ \\
\hline Cacica & - & - & 9807 & - & - \\
\hline
\end{tabular}

\section{Conclusions}

The salt mines in Romania are attractive mainly for their therapeutic and spa benefits, but also for their leisure facilities. Their attractiveness is increased by the surface tourist facilities (existence of swimming pools in Praid, Turda, Cacica, and Tg. Ocna), but especially by their geographical position, the salt mines in Romania being located near other famous tourist regions and resorts. The tourist potential of these industrial attractions is considerable, both in terms of medical tourism, practiced by people suffering from a series of diseases that can be treated with speleotherapy, but also recreational tourism, both underground and on the surface, thus capitalizing on the valuable tourist development made mainly after 2008.

The analysis of the dynamics of the number of visitors, units and accommodation capacity existing in the administrative units near the salt mines over the last three decades, shows a constant increase in tourist inbound flows in correlation with total accommodation capacity, as well as a diversification of the types of accommodation units. In this context, some salt mines manage to maximize the development investments, being promoted in tourism publications that increase their attractiveness internationally. Thus, Turda salt mine is the only one in Romania that is listed with two stars in the second edition of the green guide launched by Michelin.

However, the tourist capitalization of salt mines in Romania, even if it registers a favorable evolution in the last decades, is still incomplete. Basically, industrial tourism, a form of tourism that involves knowing the specifics of the economic activity of extracting salt from Romanian mines and visiting the mines especially for this reason, is still ignored by company administrators. Thus, the tourist activities are rather complementary to the industrial ones, the technological flow of salt extraction being presented virtually in anthropic tourist attractions located near the mines. At the same time, there are large investment gaps between the six mines we analyzed, Cacica and Ocnele Mari requiring considerable investments to increase their tourist attractiveness in the near future.

\section{References}

1. Corti, B., (1991), Archeologia industriale, Puntografico Spa, Brescia

2. Dodd, T.H., (1998), Influences on Search Behaviour of Industrial Tourists, Journal of Hospitality\&Leisure Marketing, 5 (2/3)

3. Frew E. A., (2000), Industrial tourism: A conceptual and empirical analysis, Wellington, Victoria University Press

4. Hall, C.M., Sharples, L. (2003), The consumption of experiences or the experience of consumption? An introduction to the tourism of taste In C.M.Hall, L.Sharples, R., Mitchell, N. Macionis, \& B.Cambourne (Eds.), Food tourism around the world: Development, management and markets, Oxford: Butterworth Heinemann

5. Iancu Merciu F.C., Stoica I.A., (2010), Tourist Capitalization Of Industrial Heritage Elements: A Strategic Direction Of Sustainable Development. Case Study: The Petrosani Depression, GeoJournal of Tourism and Geosites, Year III, no. 1, vol. 5

6. Innocenti, P., (2007), Geografia del turismo, terza edizione, Carocci Editore, Roma

7. Otgaar, A., (2010), Industrial Tourism-Where The Public Meets The Private, Erasmus Research Institute of Management-ERIM, Rotterdam 8. Otgaar A., Van Der Beng L., Berger C., Feng R.X., (2016), Industrial Tourism: Opportunities For City And Enterprise, Routledge, New York

9.. Macron, A., Preuilh, P., Ksouri, S., (2000), Tourisme de decouverte economique et visites d'entreprises, coll. Conseil national du tourisme, ed. La Documentation francaise

10. Preite, M., Maciocco, Gabriella, (2000), Da miniera a museo. Il recupero dei siti minerari in Europa, Alinea Editrice, Firenze

11. Plummera, R., Telfera, D., Hashimotoa, A., Summers, R., (2003), Beer tourism in Canada along the Waterloo-Wellington Ale Trail. Tourism Management, 26

12. Simonson, L.R., (1974), A study of industrial plant tours as important tourist attractions, Unpublished Doctoral Dissertation, Texas, A\&M University

13. Soyez, D. (1986), Industrietourismus, Erdkunde, 40 
14. Telfer, D., Hashimoto, A. (2002), Imaging, innovation and partnership in culinary tourism in the Niagara Region In E. Arola, J.Karkkainen, M. Siitari (Eds.) Tourism and well-being. The 2nd Tourism Industry and Education Symposium, May 16-18, 2002, Jyvaskyla, Finland

*** (2008), Ministry of Culture and National Heritage, The Ministry of Culture and Religious Affairs' strategy concerning the national cultural heritage

*** www.insse.ro, Tempo-Online Database

*** https://www.salinaturda.eu/

*** http://www.salrom.ro/slanic-prahova.php

*** https://salina.ro/

*** https://www.salinapraid.ro/salina-praid

*** http://www.salinaocnelemari.ro/

*** https://www.rri.ro/en_gb/a_tourist_in_romanias_salt_mines-2595495

*** https://www.zfro/companii/salina-turda-care-atrage-700-000-de-vizitatori-pe-an-are-o-marja-de-profit-de-30-salina-turda-a-fostredeschisa-in-2010-dupa-investiti-in-modernizare-de-sase-milioane-de-euro-18299459 